\title{
MEDIA SOSIAL INSTAGRAM SEBAGAI JARINGAN KOMUNIKASI SOCIOPRENEUR
}

\author{
Wenny Maya Arlena \\ Fakultas Komnikasi Desain Kreatif \\ Universitas Budi Luhur \\ Wenny.maya@budiluhur.ac.id
}

\begin{abstract}
Abstrak
Meningkatnya kelompok sociopreneur ikan cupang menggunakan media sosial Instagram sebagai jaringan komunikasi dalam di wilayah Tangerang memanfaatkan sebagai media penjualan, branding, promosi. Namun akhirnya berkembang hingga di luar wilayah Tangerang. Data tersebut menjelaskan total pengguna Instagram di Indonesia mencapai 59.840.000. Pengguna Instagram menunjukkan pada gender perempuan paling dominan di Indonesia. Tercatat jumlah mencapai 50,8 persen, lebih unggul dari pada pria yang hanya 49,2 persen meskipun beda tipis. Rumusan masalah dalam kajian ini adalah bagaimana media sosial Instagram sebagai jaringan komunikasi pada kelompok sociopreneur ikan cupang dalam meningkatkan produktivitas di wilayah Tangerang. Instagram memiliki fungsi dan peran sebagai media yang membantu untuk komunikasi interaktif antar kelompok sociopreneur. Kajian ini agar mengetahui media sosial Instagram sebagai jaringan komunikasi pada kelompok sociopreneur ikan cupang dalam meningkatkan produktivitas di wilayah Tangerang terjalin komunikasi interaktif yang dapat memberikan informasi bermanfaat bagi banyak orang khususnya bagi pemula yang ingin memulai atau mencoba berbisnis ikan cupang (peternak, jocky, breeder, pemain kontes, pecinta, juri kontes) dapat mereka lakukan sesuai yang dibutuhkan. Kajian ini menggunakan pendekatan kualitatif, karena ingin menggali informasi lebih mendalam bagaimana Instagram sebagai media sosial yang digunakan komunikasi antara kelompok sociopreneur ikan cupang melalui jaringan komunikasi di wilayah Tangerang dalam meningkatkan produktivitas. Hasil Kajian ini menggunakan teori konvergensi interaksi simbolik dengan menganalisa tingkatan jaringan komunikasinya sebagai berikut: 1. Tingkatan Individu, 2. Tingkat Klik, 3. Tingkat sistem. Dengan demikian maka dapat terjalin kedekatan yang dapat menciptakan sebuah motivasi untuk dapat terus meningkatkan produktifitas dan bisnis mereka secara online, hal ini juga dapat menjadikan acuan untuk dapat hidup lebih baik, sejahtera dan makmur secara lahir dan batin di dalam kelompok percupangan.
\end{abstract}

Kata kunci: Instagram, Jaringan Komunikasi, Sociopreneur, Produktifitas

\section{PENDAHULUAN}

\section{Latar Belakang}

Di era globalisasi teknologi setiap tahunnya berkembang bersamaan dengan jaman, membuat suatu tantangan dan peluang bisnis besar serta baru bagi dunia. Permasalahan yang dihadapi adalah bertambahnya jumlah populasi penduduk yang tidak seimbang dengan perkembangan jumlah sociopreneur yang ada. Permasalahan lain yaitu banyak masyarakat yang ingin membuka usaha secara mandiri, tetapi tidak mempunyai modal/dana, masyarakat juga kurang mengetahui hal apa saja yang harus dilakukan oleh seorang usahawan mandiri. Banyak sociopreneur muda bermunculan namun kurang memiliki rasa kepedulian terhadap bangsa Indonesia, tipe seperti ini mereka hanya akan memperkerjakan orang-orang yang memiliki pendidikan tinggi saja dan bisnis atau usaha yang dibuka tidak memberikan dampak yang besar untuk masyarakat, khususnya masyarakat disekitarnya.

Adanya teknologi mempermudah manusia dalam berkomunikasi dan mencari informasi. Perkembangan teknologi yang pesat melahirkan suatu era komunikasi interaktif yang ditandai dengan kemunculan internet. Dengan adanya internet, masyarakat dapat menerima informasi secara cepat tanpa terhalang jarak dan waktu, serta menjangkau semua kalangan masyarakat. (Tamburaka, 2013: 73). Media sosial di 
era globalisasi saat ini memiliki peran penting bahkan menjadi media utama bagi lembaga-lembaga pemerintah dan swasta. Tidak hanya itu, mulai dari akun pribadi hingga resmi. Berbagai platform memudahkan penggunanya dalam melakukan komunikasi mulai dari jangkauan tertentu bahkan yang lebih luas, berbagai aplikasi yang disuguhkan seperti Instagram, facebook, line, whatsapp, youtube, dan lain sebagainya.

Instagram adalah salah satu media sosial yang saat ini berkembang pesat digunakan oleh semua kalangan bahkan lembaga resmi di Indonesia, sebagai media komunikasi promosi, marketing, bahkan branding. Dengan adanya fungsi Instagram tidak hanya digunakan pada kepentingan individual saja, namun seringkali dimanfaatkan sebagai penggerak tumbuhnya gerakan sosial baru di masyarakat. Instagram menjadi wadah berkumpulnya suatu komunitas untuk mempermudah manusia berinteraksi dan berkomunikasi. (Lilis dan Yugih, 2018: 401). Data menunjukkan pada bulan November 2019 jumlah pengguna aktif bulanan Instagram di Indonesia telah mencapai 61.610.000. Data ini diambil dari salah satu perusahaan analisis Sosial Media Marketing yang berlokasi di Warsawa, Polandia. Hal ini artinya 22,6 persen atau sekitar seperempat total penduduk Indonesia adalah pengguna Instagram. Berikut data yang disampaikan:

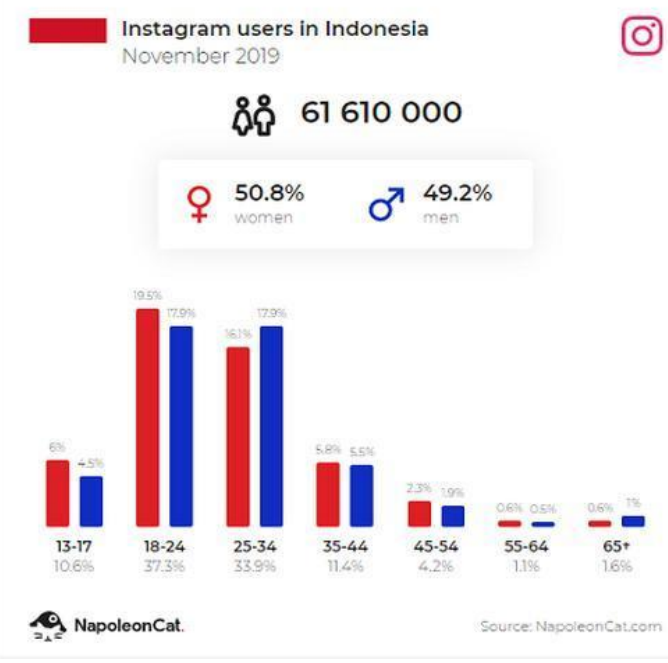

Gambar 1. Pengguna Instagram di Indonesia Sumber: NapoleonCat.com

Data tersebut menjelaskan total pengguna Instagram di Indonesia mencapai 59.840.000. Pengguna Instagram menunjukkan pada gender perempuan paling dominan di Indonesia. Tercatat jumlah mencapai 50,8 persen, lebih unggul dari pada pria yang hanya 49,2 persen meskipun beda tipis. (Pertiwi, Wahyunanda Kusuma, 2020). Usia pengguna Instagram antara 18-24 tahun merupakan kelompok usia yang paling besar di Indonesia, dengan total 37,3 persen atau sekitar 23 juta pengguna. Pengguna Instagram perempuan masih dominan yaitu sekitar 19,5 persen bila dibandingkan dengan laki-laki hanya sekitar 17,9 persen. Selanjutnya untuk pengguna Instagram terbesar kedua pada kelompok usia 25-34 tahun dengan besar persentase sekitar 33,9 persen. Berbeda dengan kelompok usia sebelumnya, yaitu kategori usia ini

justru lebih unggul pada pengguna pria sebesar 17,9 persen dan sementara pengguna kelompok perempuan sebesar 16,1 persen. Sementara dari sisi jumlah pengguna pria lebih unggul 1,1 juta. Dari kategori usia pengguna Instagram yang paling rendah adalah 65 tahun ke atas yang persentasenya sebesar 1,6 persen. 
Jaringan Komunikasi adalah penggunaan analisis jaringan sosial dalam bidang ilmu komunikasi (Eriyanto, 2014: 23) atau dapat dikatakan bahwa analisis jaringan komunikasi pada dasarnya adalah penerapan dari analisis jaringan sosial (Social Networking Analysis) pada bidang komunikasi. Melalui pola jaringan komunikasi dapat diketahui bagaimana tahapan suatu informasi dapat tersebar dan siapa saja yang berperan penting dalam penyebaran informasi. Komunikasi berbasis internet memberikan cara baru untuk berinteraksi dengan teman dan orang asing, dengan cara baru untuk mempelajari dunia, identitas dan masa depan. Hubungan antara perangkat mobile dan web interaksi melalui jaringan sosial telah menjadi standar dalam komunikasi digital. Sociopreneur beberapa waktu terakhir di Indonesia mulai berkembang dan mencuri perhatian di masyarakat, hal ini membawa dampak positif yang dapat dirasakan secara langsung oleh masyarakat serta inovasi saat ini menjadikan bisnis di bidang sosial tidak lagi dipandang sebelah mata. Dapat kita lihat mulai dari kalangan menengah atas dari pengusaha sampai dengan berbagai macam media massa terlibat dalam perkembangan sociopreneur di Indonesia.

Dampak positif perkembangan sociopreneur di Indonesia dapat dilihat dari struktur ekonomi Indonesia secara spasial pada triwulan I-2020 didominasi oleh kelompok provinsi di Pulau Jawa dan Pulau Sumatera. Kelompok provinsi di Pulau Jawa memberikan kontribusi terbesar terhadap PDB Indonesia, yakni sebesar 59,14 persen, diikuti oleh Pulau Sumatera sebesar 21,40 persen, Pulau Kalimantan sebesar 8,12 persen, dan Pulau Sulawesi sebesar 6,19 persen, serta Bali dan Nusa Tenggara sebesar 2,95 persen. Sementara kontribusi terendah ditorehkan oleh kelompok provinsi di Pulau Maluku dan Papua. (Badan Pusat Statistik. 2020)
Fenomena perkembangan pecinta, peternak, jocky, breeder, pemain kontes, hingga penjual ikan cupang di Indonesia berkembang pesat. Dalam kajian ini beberapa sociopreneur ikan cupang di wilayah Tangerang Kota, salah satunya adalah Indonesian Super hmpk yang berada di wilayang Kota Bumi, Tangerang, Instagramnya adalah @indonesiansuperhmpk. Yang melatar-belakangi kajian ini adalah berawal dari fenomena masyarakat yang melihat ikan cupang adalah sekedar ikan hias, ikan aduan, atau ikan sebagai mainan anak-anak usia sekolah dasar, yang dijual dengan harga murah, mudah di dapat dan dibeli oleh siapa saja, selain itu proses perawatannya sangat mudah, cukup ditempatkan dalam kaca disetiap ikannya, tanpa harus menggunakan oksigen, cukup dengan suhu udara ruang saja. Makanannya pun cukup mudah didapat, seperti anakan cacing, pelet dari bentuk alami hingga instan dan hargapun terjangkau. Dulu ikan cupang disebut sebagai ikan aduan. Ikan cupang memiliki bentuk dan karakter yang unik dan cenderung agresif dalam menjaga atau mempertahankan wilayah dirinya. Di kalangan pecinta ikan cupang pada umumnya terbagi atas tiga golongan yaitu cupang liar, cupang hias dan cupang aduan. Di Indonesia terdapat ikan cupang yang asli, salah satunya adalah Betta channoides yang ditemukan di Pampang, Kalimantan timur (Wawancara, Dalyano (Adon): 11 Februari 2020). Saat ini banyak bermunculan para sociopreneur ikan cupang di Indonesia, di wilayah Jawa seperti Jakarta, Tangerang, Yogyakarta, Jawa Timur. Bahkan di wilayah Kalimantan Timur, Sumatera seperti Pekanbaru.

Komunikasi melalui Instagram tidak hanya melalui komen, like dan direct message, tetapi saat ini dapat juga melalui live Instagram dan instastory. Komunikasi yang biasa mereka lakukan 
mempertanyakan bagaimana memilih ikan cupang yang sehat, cara membuat pakan alami, cara membedakan ikan cupang jantan dan betina, cara beternak, usia berapa bulan untuk bisa mengikuti kontes, cara menjual dan memasarkan, cara memelihara dan merawat dengan baik standar pada umumnya, dan masih banyak lagi yang mereka diskusikan. Selain itu ada media youtube juga sebagai media komunikasi secara interaktif, namun tidak seefektif dan sesering Instagram.

Mereka memiliki visi dan misi, yaitu ingin ikan cupang masuk dalam kategori hewan yang dilindungi, memiliki kualitas SNI (Standar Nasional Indonesia), melihat hal ini mereka sering mengikuti kontes ikan cupang mulai dari tingkat daerah hingga tingkat nasional, bahkan ada yang mengikuti kontes internasional yaitu IBC (International Betta Contes) (Wawancara, Dalyano: 11 Februari 2020). Mereka saling bekerjasama dengan baik setiap sociopreneur jika adalah salah satu dari kelompok mereka ada masalah, mereka berusaha saling membantu untuk memecahkan masalah, ingin meningkat-kan kesejahteraan perekonomian hidup para pembudidaya ikan cupang lebih layak secara merata, jaringan komunikasi lebih luas jangkauannya di seluruh Indonesia. Meskipun demikian mereka juga memiliki persaingan positif antar sociopreneur, seperti persaingan bisnis yaitu penjualan ikan cupang, dengan dasar kualitas ikan menentukan harga, kualitas pakan, cara memelihara, ikan kontes dengan yang tidak pernah mengikuti kontes juga memiliki nilai yang berbeda.

Menurut hasil survey Indonesia Best Cities for Business tahun 2016 yang dilakukan oleh majalah SWA Indonesia, Tangerang Kota masuk dalam urutan nomor tiga dan Tangerang masuk pada urutan nomor lima kota di Indonesia yang menjadi salah satu pilihan untuk berbisnis atau investasi. Survei ini dilakukan dengan melihat delapan parameter dari infrastruktur, lahan, perijinan, tenaga kerja, dukungan Pemerintah Daerah, pajak daerah, keamanan berbisnis, dan pelayanan yang bersifat terpadu (Diah, Partini, Peni, 2018: 13). Tangerang Kota memiliki indeks kota terbaik sebesar 78,25 dengan jumlah penduduk usia produktif mencapai 62,5\% (2015), kota Tangerang memiliki potensi meraih pertumbuhan yang tinggi. Wilayahnya menjadi tempat investasi yang prospektif, ditunjang oleh infrastruktur dan utilitas yang memadai dan lengkap seperti adanya Universitas, Bandara Internasional Soekarno-Hatta, Pemerintah Kota yang memberikan dukungan pada pendidikan yang secara terus menerus ditingkatkan. $\mathrm{Hal}$ ini menjadi penting untuk pengembangan kualitas SDM. (Diah, Partini, Peni, 2018: 13-14). Pada posisi urutan kelima adalah Tangerang dengan index Kota Terbaik sebesar 77,37 dimana memiliki daerah pertumbuhan di wilayah Barat yaitu Tigaraksa dan Balaraja, dititikberatkan sebagai daerah pusat industri, pusat pemerintahan dan pemukiman (Diah, Partini, Peni, 2018: 14).

Rumusan masalah dalam kajian ini adalah bagaimana media sosial Instagram sebagai jaringan komunikasi pada kelompok sociopreneur ikan cupang dalam meningkatkan produktivitas di wilayah Tangerang. Dimana Instagram memiliki fungsi dan peran sebagai media yang membantu untuk komunikasi interaktif antar kelompok sociopreneur. Komunikasi mereka biasanya dilakukan melalui postingan konten ikan cupang di Instagram sebagai jaringan komunikasi pada kelompok sociopreneur ikan cupang dari salah satu kelompok mereka, kemudian terjadi komunikasi melalui like, comment, direct message bahkan melalui instastory atau live Instagram. 
Tujuan dalam kajian ini agar mengetahui media sosial Instagram sebagai jaringan komunikasi pada kelompok sociopreneur ikan cupang dalam meningkatkan produktivitas di wilayah Tangerang terjalin komunikasi interaktif yang dapat memberikan informasi bermanfaat bagi banyak orang khususnya bagi pemula yang ingin memulai atau mencoba berbisnis ikan cupang (peternak, jocky, breeder, pemain kontes, pecinta, juri kontes) dapat mereka lakukan sesuai yang butuhkan.

\section{TINJAUAN LITERATUR}

\section{Media sosial}

Media sosial adalah bentuk yang tidak juh berbeda dengan keberadaan dan cara mengerjakan cara kerja komputer. Tiga bentuk bersosial, seperti pengenalan, komunikasi, dan kerjasama bisa dianalogikan dengan cara komputer yang juga membentuk sebuah sistem bagaimana adanya sistem di antara individu atau masyarakat. Bentuk-bentuk itu merupakan lapisan dimana lapisan peta menjadi dasar untuk terbentuknya lapisan lain, pengenalan pada dasarnya merupakan dasar untuk berkomunikasi dan komunikasi merupakan dasar untuk melakukan kerjasama (Rulli, 2015: 10). Selain itu definisi media sosial menurut Meike dan Young (2013) yang dikutip oleh Rulli, media sosial mengartikan kata media sosial sebagai konvergensi antara komunikasi personal dalam arti saling berbagi antara individu (to be shared one-to-one) dan media publik untuk berbagi kepada siapa saja tanpa ada kekhususan individu (Rulli, 2015: 11). Menurut Van Dijk (2013) dijelaskan oleh Rulli, media sosial adalah platform media yang memfokuskan pada eksistensi pengguna yang memfasilitasi mereka dalam beraktivitas maupun berkolaborasi. Karena itu, media sosial dapat dilihat sebagai medium (fasilitator) online menguatkan hubungan antarpengguna sekaligus sebagai sebuah ikatan sosial. (Rulli, 2015: 11). Dari beberapa penjelasan definisi di atas maka dapat dijelaskan bahwa media adalah medium internet dimana penggunanya dapat memperkenalkan dirinya kepada publik bahwa melalui media sosial individu dapat melakukan interaksi, berbagi, berkomunikasi antar pengguna satu dengan yang lainnya, dapat bekerjasama hingga mereka membentuk suatu kelompok atau ikatan sosial secara virtual dan non-virtual dengan kesepakatan bersama kapan waktu dan tempatnya mereka dapat berinteraksi secara langsung. Adapun karakteristik media sosial adalah jaringan (network), informasi (information), arsip (archive), interaksi (interactivity), simulasi sosial (simulation of society), konten oleh pengguna (user-generated content) (Rulli, 2015: 16).

\section{Instagram}

Instagram berasal dari nama insta yang mengandung arti instan. Seperti kamera polaroid pada masanya dikenal dengan nama "foto instan". Instagram dapat menampilkan foto-foto secara instan, video durasi maksimal 60 detik, instastory foto atau video dengan durasi maksimal 15 detik, hingga berkembang IGTV untuk durasi lebih dari 60 detik. Kata gram berasal dari kata telegram dimana cara kerja telegram untuk mengirimkan informasi kepada orang lain secara luas dengan cepat. Seperti Instagram dapat mengunggah foto dan video dengan menggunakan jaringan internet, sehingga informasi yang ingin disampaikan dapat diterima dengan cepat (Neng, Riche, Gema, 2018: 6).

\section{Social Entepreneur}

Menurut Dees dalam Wibowo dan Hery (2015: 19) para social entrepreneur bertindak sebagai agen perubahan dalam sector sosial dengan: 
1. Mengadopsi sebuah misi untuk meciptakan dan mempertahankan nilai-nilai sosial.

2. Mengenali dan mengusahakan pelunga-peluang baru untuk menjamin keberlangsungan misi tersebut.

3. Melibatkan diri dalam sebuah proses inovasi adaptasi dan belajar yang berkelanjutan.

4. Berindak penuh semangat walaupun dengan keterbatasan sumber.

5. Penuh intensitas dalam semangat akuntabilitas pada konstituen dan pada usaha-usaha yang telah ditetapkan.

Wibowo juga mengungkapkan social entrepreneur adalah usaha untuk merespon tantangan sosial, dimana setiap orang mampu menjadi agen perubahan yang percaya diri dalam mengatasi masalah sosial dan mendorong perubahan sosial dengan dukungan penuh dari lingkungan sosialnya. (Wibowo, Hery, 2015: 18). Karena faktor utama dukungan mulai dari lingkungan terdekat merupakan dasar utama untuk terus bergerak menjalankan tugasnya sebagai agen perubahan. Hal ini memang harus dilakukan secara terus menerus dengan segala resiko yang terjadi. Seorang sociopreneur tidak hanya menguntung-kan bisnis atau usahanya semata, harus memiliki jiwa sosial yang tinggi, karena tanpa disadari bahwa masyarakat yang memberikan faktor besar atau peran yang cukup dalam sebuah perubahan.

Social entrepreneur terdiri dari empat elemen utama yaitu social value, civil society, innovation, and economic activity. (Palengsangi, 2013) dalam Irma (2015: 6):

1. Social Value. Social entrepreneur merupakan elemen paling khas yaitu menciptakan manfaat sosial yang nyata bagi masyarakat dan lingkungan sekitar.

2. Civil Societ. Social entrepreneur pada umtumnya berasal dari inisiatif dan partisipasi masyarakat sipil dengan mngoptimalkan modal sosial yang ada di masyarakat.

3. Innovation. Social entrepreneur dalam hal ini mampu memecahkan masalah sosial dengan cara-cara inovatif antara lain kearifan local dan inovasi sosial.

4. Economic activity, social entrepreneur yang berhasilm pada umumnya dengan menyeimbangkan antara aktivitas sosial dengan aktivitas bisnis. Aktifitas bisnis/ekonomi dikembang-kan untuk menjamin kemandirian dan keberlanjutan misi sosial organisasi.

Social entrepreneur saat ini berada dipersimpangan jalan antara non-provit dan organisasi murni bisnis sebagaimana digambarkan dalam gambar yang dikemukakan Alter (2006) dalam Irma (2015: 6): berikut ini:

\section{Hybrid Spectrum}

\begin{tabular}{|c|c|c|c|c|c|}
\hline $\begin{array}{l}\text { Traditional } \\
\text { Nonprofit }\end{array}$ & $\begin{array}{c}\text { Nonprofit } \\
\text { with } \\
\text { Income-Ge } \\
\text { nerating } \\
\text { Activities }\end{array}$ & $\begin{array}{c}\text { Social } \\
\text { Enterprise }\end{array}$ & $\begin{array}{c}\text { Socially } \\
\text { Responsible } \\
\text { Business }\end{array}$ & $\begin{array}{c}\text { Corporation } \\
\text { Practicing } \\
\text { Social } \\
\text { Responsibility }\end{array}$ & $\begin{array}{l}\text { Traditional } \\
\text { For-Profit }\end{array}$ \\
\hline
\end{tabular}

Mission Motive - - Profit-making Motive

Stakeholder Accountability - - Shareholder Accountability

Income reinvested in social programs or - - Profit redistributed to shareholders 
Gambar 2. Sumber Typology of Social Enterpreneurs (Alter, 2006)

\section{Jaringan Komunikasi}

Jaringan secara sederhana dapat didefinisikan sebagai seperangkat hubungan di antara aktor-aktor sosial (Kadushin, 2012: 14). Dari penjelasan definisi tersebut, ada dua hal penting dari analisis jaringan, yaitu pelaku/aktor dan hubungan antar pelaku/tokoh. Jaringan komunikasi menurut Rogres (1981), adalah suatu jaringan yang terdiri dari individu-individu yang saling dihubungkan oleh arus komunikasi yang terpola. Selain itu, jaringan komunikasi juga sebagai suatu jenis hubungan yang secara khusus merangkai individu-individu, ojek-objek, dan peristiwa-peristiwa. Sedangkan Freire dalam Rogres (1981) melihat jaringan komunikasi sebagai pola yang teratur dapat diidentifikasi sebagai pertukaran informasi yang dialami seseorang di dalam sistem sosialnya.

Jaringan komunikasi merupakan gambaran "bow talk to whom" (siapa berbicara kepada siapa) dalam suatu sistem sosial. Jaringan komunikasi menggambarkan komunikasi interpersonal, dimana terdapat pemuka-pemuka opini dan pengikut yang saling memiliki hubungan komunikasi pada suatu topik tertentu, yang terjadi dalam suatu sistem sosial tertentu, seperti sebuah komunitas, organisasi, ataupun perusahaan. (Rogres and Kincaid, 1981: 79). Beberapa penjelasan pengertian tadi dapat disimpulkan bahwa jaringan komunikasi dalam penelitian ini merupakan rangkaian hubungan antara individu sebagai akibat terjadinya pertukaran informasi, sehingga dapat membentuk beberapa model atau pola-pola pada jaringan komunikasi tertentu bahkan jaringan komunikasi baru berdasarkan penemuan yang ada.

Jaringan komunikasi menurut Eriyanto (2014) dibagi mejadi dua bagian, yaitu jaringan utuh (complete networks) dan jaringan yang berpusat pada ego (ego networks). Perbedaan pada keduanya ini terletak pada apakah analisis memusatkan perhatian hanya pada satu atau beberapa aktor (node), ataukah melihat dan memperhitungkan semua aktor (node) dalam jaringan yang berpusat pada ego, hanya saja harus memusatkan perhatian pada aktor (node) tertentu. Aktor dan kelompok yang diamati tersebut sesuai dengan tujuan penelitian.

Table 1. Tabel Analisis Desain Studi

\begin{tabular}{|c|c|c|}
\hline \multirow[b]{2}{*}{ LEVEL ANALISIS } & \multicolumn{2}{|c|}{ DESAIN STUDI } \\
\hline & $\begin{array}{c}\text { Jaringan Utuh } \\
\text { (Complete Network) }\end{array}$ & $\begin{array}{c}\text { Jaringan Berpusat Ego } \\
\text { (Ego Networks) }\end{array}$ \\
\hline $\begin{array}{l}\text { Aktor } \\
\text { (Tunggal) }\end{array}$ & $\begin{array}{ll}\text { - } & \text { Sentralisasi Tingkatan } \\
\text { - Sentralisasi Kedekatan } \\
\text { - Sentralisasi } \\
& \text { Keperantaraan } \\
\text { - } & \text { Sentralisasi Eigenvektor } \\
\end{array}$ & $\begin{array}{l}\text { - Ketutupan jaringan } \\
\text { - Celah Struktur } \\
\text { - Kekuatan Ikatan }\end{array}$ \\
\hline $\begin{array}{l}\text { Kelompok } \\
\text { (group) }\end{array}$ & $\begin{array}{ll}\text { - } & \text { Komponen } \\
\text { - } & \text { K-cone } \\
\text { - Klik } \\
\text { - } \\
\text { - } \\
\end{array}$ & $\begin{array}{l}\text { - Broker } \\
\text { - Analisis Homofili } \\
\text { - Kesetaraan Posisi }\end{array}$ \\
\hline Sistem & $\begin{array}{ll}\text { - } & \text { Ukuran } \\
\text { - } & \text { Kepadatan } \\
\text { - } & \text { Resiprositas }\end{array}$ & $\begin{array}{l}\text { - Ukuran } \\
\text { - Kepadatan } \\
\text { - Diameter dan jarak }\end{array}$ \\
\hline
\end{tabular}


- Diameter dan jarak

Sumber: jaringan Komunikasi (Eriyanto, 2014: 168)

\section{Produktivitas}

Produktivitas menurut Sinungan (1995) dikelompokkan menjadi tiga bagian, yaitu:

1. Rumusan tradisional bagi seluruh produktivitas tidak lain ialah rasio dari apa yang dihasilkan terhadap kseluruhan peralatan produksi yang digunakan.

2. Produktivitas pada dasarnya adalah sikap mental yang selalui mempunyai pandangan bahwa mutu kehidupan hari ini lebih baik daripada kemarin, dan hari esok lebih baik dari hari ini.

3. Produktivitas merupakan interaksi terpadu secara serasi dari tiga faktor esensial, yakni a. investasi, termasuk penggunaan pengetahuan, teknologi, serta riset, b. manajemen dan c. tenaga kerja.

Kajian yang dimaksud dengan produktivitas adalah bagaimana aktor dan anggota kelompok sociopreneur ikan cupang meningkatkan kualitas ikan cupang SNI di seluruh Indonesia pada umumnya.

\section{Teori Konvergensi Simbolik}

Teori Konvergensi Simbolik merupakan teori umum yang membahas fenomena pertukaran sebuah pesan yang memunculkan keadaan pada sebuah kelompok hingga berimplikasi pada hadirnya sebuah motif, makna dan perasaan bersama, hal ini disampaikan Hirokawa dan Pole (1986) dalam Suryadi (2010). Teori Konvergensi Simbolik, Bormann (1990) mengartikan istilah konvergensi sebagai suatu cara dimana dunia simbolik pribadi dari dua atau lebih individu saling bertemu, mendekat atau bahkan saling berhimpitan satu dengan yang lainnya (Suryadi, 2010). Simbolik itu sendiri terkait dengan kecenderungan manusia untuk memberikan penafsiran dan menanamkan makna kepada berbagai lambang, tanda, kejadian yang tengah dialami, atau bahkan tindakan yang dilakukan manusia (Bormann, 1986). Bormann juga mengatakan bahwa manusia adalah simbol user, yaitu manusia menggunakan simbol dan berkomunikasi secara umum ataupun dalam bercerita (Suryadi, 2010). Saat kelompok berbagi symbol bersama, komunikasi menjadi lebih mudah dan efisien hal ini disebabkan "a meeting of mind" yaitu pertemuan pada frekuensi pemikiran. (Infante, et al, 1993). Jika sebuah pikiran yang saling dipertemukan tidak dipungkiri setiap orang mulai melakukan gerakan pada arah penggunaan sebuah sistem simbol yang sama.

Pemikiran yang saling pengertian kemudian dijadikan sebagai dasar untuk menciptakan kesadaran bersama, perasaan, dan kesamaan dalam pemikiran tentang berbagai macam hal yang mereka perbincangkan. Kajian ini akan memberikan sebuah gambaran, bagaimana Instagram sebagai jaringan komunikasi pada sebuah kelompok peternak hingga penjual ikan cupang dapat mendorong terciptanya produktivitas sesama sociopreneur. Selain itu komunikasi melalui Instagram dapat dilakukan secara kontinyu dengan membahas masalah kelompok percupangan di wilayah Tangerang, hingga dapat terjadinya pertemuan secara lansung, sehingga para kelompok sociopreneur ini untuk saling berbagi simbol terkait strategi penjualan, peningkatan kualitas ikan cupang, budidaya ikan cupang, kontes ikan cupang agar dapat mensejahterakan masyarakat luas dari sisi eknomi dan ikan cupang mendapatkan apresiasi dengan melalui jaringan komunikasi. Dengan hal 
seperti ini, dapat mencipatakan kesadaran bersama, kesamaan pemikiran, kesamaan visi dan misi serta tentang perasaaan mengenai hal-hal yang didiskusikan atau diperbincangkan. Oleh karena itu, sebuah fenomena dapat dikatakan kajian ini sejalan dengan pemikiran Teori Konvergensi Simbolik.

\section{METODE KAJIAN}

Metode yang digunakan dalam kajian ini menggunakan pendekatan kualitatif, karena ingin menggali informasi lebih mendalam bagaimana Instagram sebagai media yang digunakan komunikasi antara kelompok sociopreneur ikan cupang melalui jaringan komunikasi di wilayah Tangerang dalam meningkatkan produktivitas. Paradigma konstruktivisme yang digunakan dalam kajian ini bertujuan agar penulis secara subjektif dapat memberikan makna serta sudut pandang dan pengembangan pada pengalaman penulis dengan membaca literatur yang dipelajari. Kajian ini menggunakan studi kasus. Studi kasus adalah strategi dimana di dalamnya penulis menyelediki secara cermat suatu program, peristiwa, aktifitas, proses atau sekelompok individu. Kasus-kasus dibatasi oleh waktu dan aktifitas dan mengumpulkan informasi secara lengkap dengan menggunakan berbagai prosedur pengumpulan data berdasarkan waktu yang telah ditentukan (Creswell, 2008: 19).

\section{PENYAJIAN HASIL KAJIAN}

Kajian ini bertujuan mengetahui melalui media sosial Instagram pola jaringan komunikasi dalam meningkatkan produktifitas sociopreneur pada kelompok ikan cupang di wilayah Tangerang. Berdasarkan hasil observasi dan wawancara, dapat diketahui bahwa Indonesia Super Hmpk memiliki banyak kegiatan yang bertujuan untuk menjaga hubungan baik antar kelompok sociopreneur ikan cupang, sekaligus untuk meningkatkan kredibiltas dan kapabilitas jaringan komunikasi kelompok itu sendiri, dalam meningkatkan produk-tifitasnya melalui Instagram yaitu online maupun offline.

Kajian ini menggambarkan jaringan komunikasi yang dibentuk oleh kedua sociopreneur yaitu Indonesian Super Hmpk dan Boston Beta yaitu:

1. Tingkatan Individu

Dilihat dari data Instagram antara Indonesia Super Hmpk dengan Boston Betta, individu lainnya banyak yang memilih Indonesian Super Hmpk, dari jumlah follower di Instagram. Indonesian Super Hmpk memang fokus pada Ikan Cupang SNI yaitu Standar Nasional Indonesia dengan jumlah pengikutnya di Instagram sebanyak 16,7K (16.700). Sedangkan Boston Betta yang fokus pada IBC yaitu International Betta Contest jumlah pengikutnya sebanyak 13,9K (13.900) data diambil dari Instagram masing-masing.

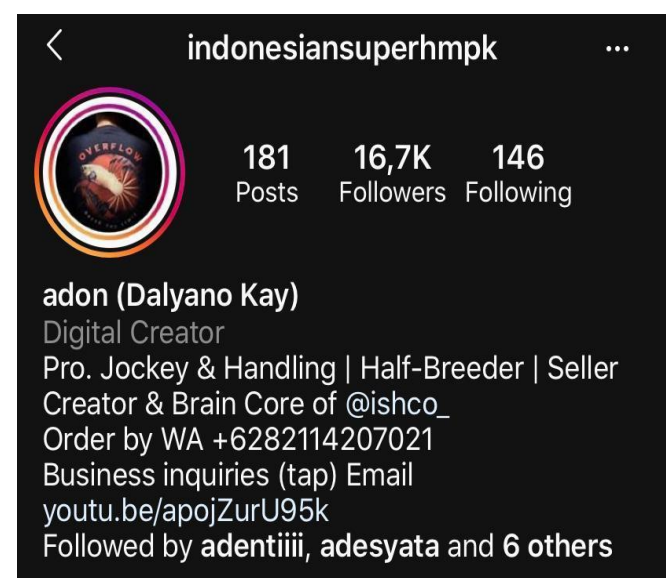

Gambar 3. Instagram Indonesian Super Hmpk/SNI

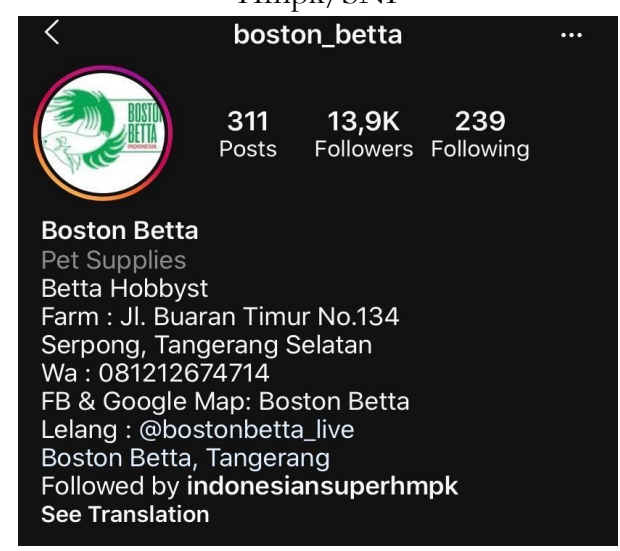


Gambar 4. Instagram Boston Betta/IBC

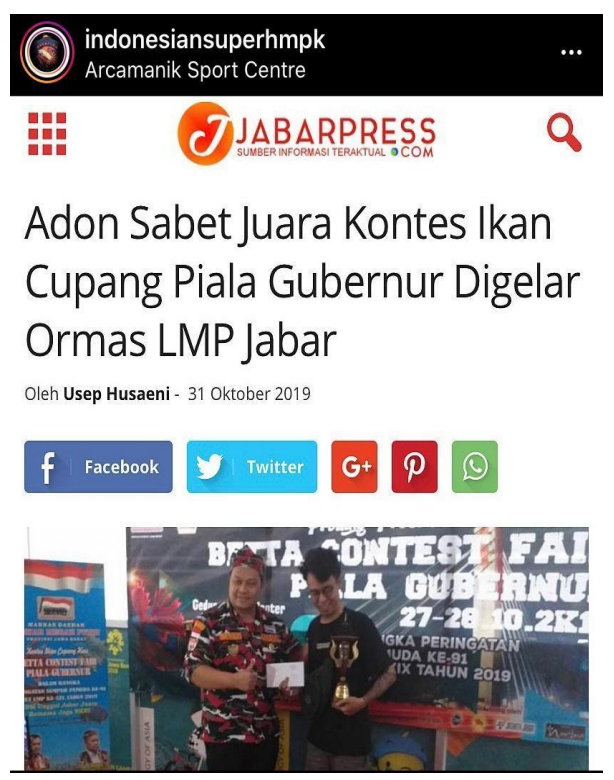

Gambar 5. Juara Kontes Ikan Cupang di Bandung

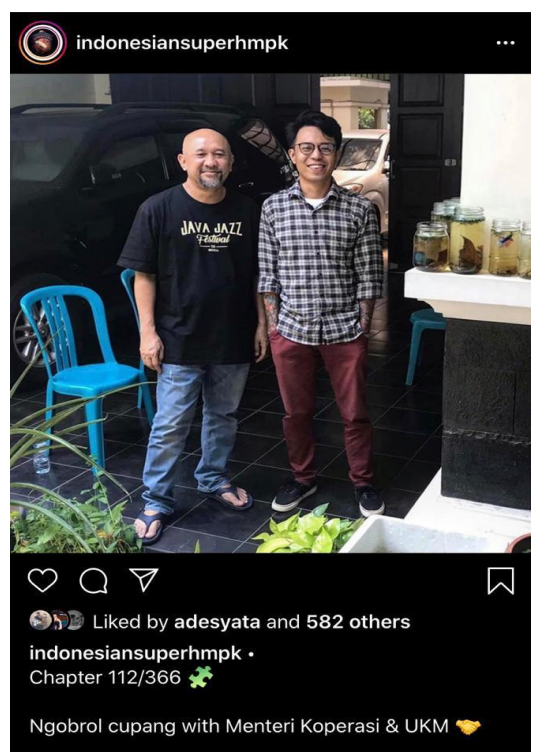

Gambar 6. Pertemuan Indonesia Super Hmpk dengan Menteri UMKM Bp. Teten Masduki.

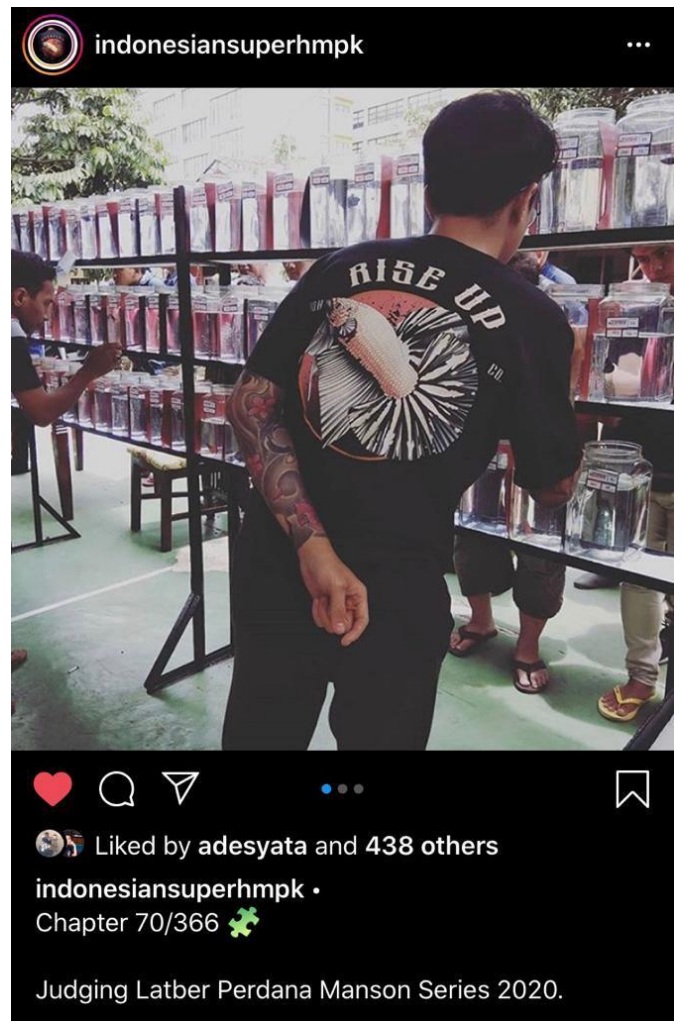

Gambar 7. Indonesia Super Hmpk sebagai juri pada salah satu kegiatan konten Cupang

Data Instagram menunjukkan bahwa jaringan komunikasi keduanya memiliki potensi yang lebih luas, tidak hanya di wilayah Kota Tangerang dan Tangerang Selatan saja, namun lebih dari itu. Indonesian Super Hmpk menunjukkan kelompok sociopreneur SNI mereka ada yang dari Kalimantan Timur, Sukabumi Jawa Barat, Surabaya dan Sumatera. Sedangkan kelompok IBC juga tidak hanya di wilayah Tangerang tetapi dari Sumatera, Kalimantan, dan Bandung Jawa Barat. Sehingga dapat disimpulkan bahwa keduanya merupakan individu yang banyak dipilih dan memiliki peranan penting di dalam kelompoknya, seperti memberikan informasi dan sebagai pusat menanyakan apapun tentang berlang-sungnya kegiatan kelompok cupang di wilayang Tangerang. 2. Tingkat Klik

Kajian ini menganalisa satu klik. Klik merupakan kedekatan yang membuat individu yang membuat individu di 
dalam kelompok atau komunitas saling melakukan komunikasi secara intens, juga memberikan informasi terlebih dulu kepada individu yang dirasa dekat dan dapat dipercaya untuk membantu menyebarkan lagi kepada anggota kelompok lainnya yang belum mendapatkan informasi secara jelas.
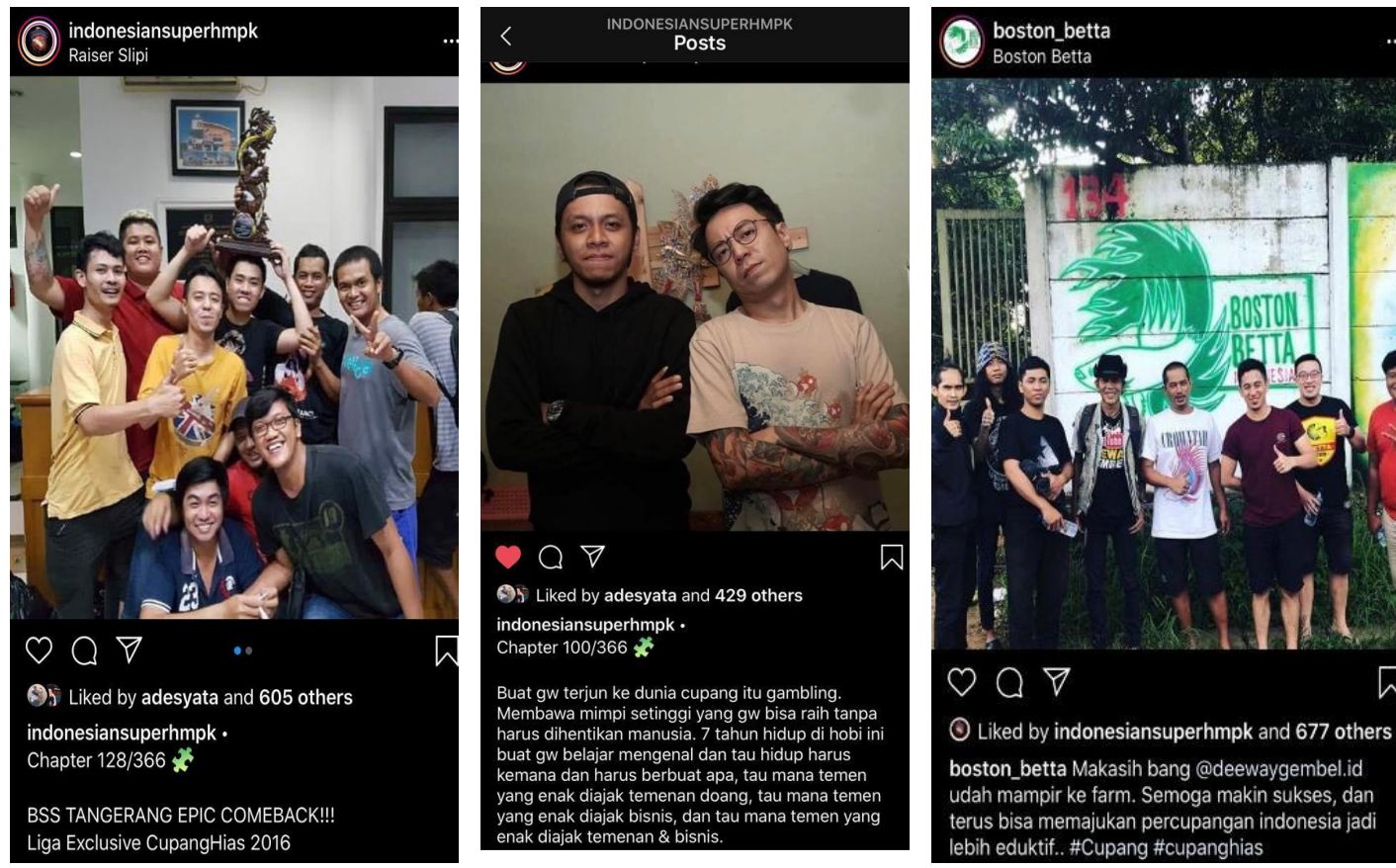

Gambar 8. Tingkat klik kelompok dan individu Indonesia Super Hmpk dan Boston Betta.

3. Tingkat Sistem

Kajian ini menganalisa adanya hubungan kelompok sociopreneur di wilayah Tangerang dengan kelompok lain yang secara langsung melakukan komunikasi dan berbagi informasi, karena adanya derajat yang sama dalam keterbukaan antar individu di dalam maupun diluar kelompok mereka. Berikut salah satu bentuk kegiatan yang dilakukan oleh Indonesia Super Hmpk melalui acara Rise Up yang diselenggarakan pada 11 Januari 2020 yang berlokasi di café Maiga Tangerang, mulai pukul 13:00 - 17:00. Peserta mulai dari wilayah Tangerang, Jakarta dan yang tejauh adalah dari Sukabumi. Berikut foto kegiatan tersebut:

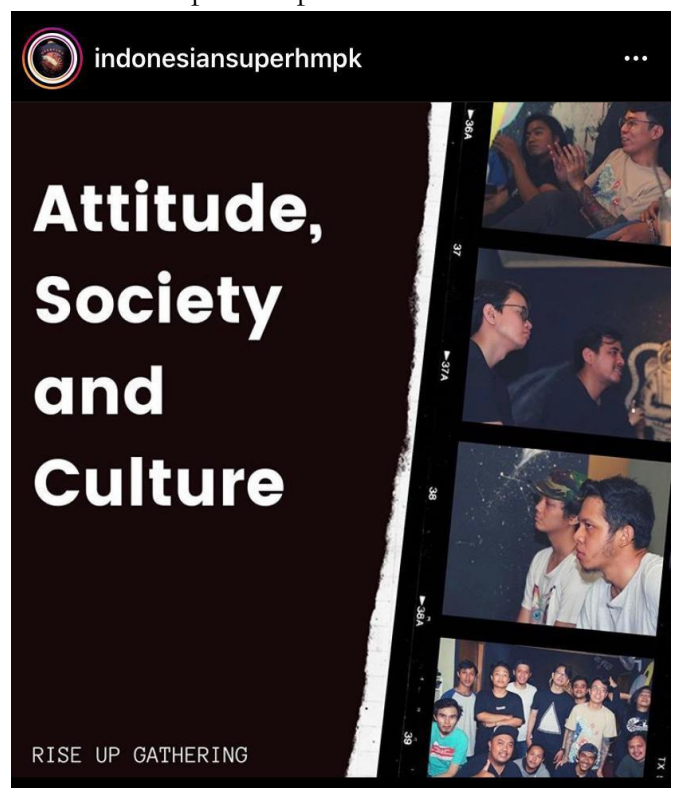

Gambar 9. Kegiatan Rise Up Indonesia Super Hmpk.

Selain itu mereka juga melakukan kegiatan secara online dengan melalui live Instagram@Boston_Betta. Acara berlangsung pada 16 Mei 2020, mulai 
pukul 21:00 - 23:00, disinilah tempat mereka saling berbagi informasi, saling memberikan dukungan satu dengan lainnya, bertukar ide untuk kedepannya bagaimana keberadaan kelompok ikan cupang di Indonesia secara umum.
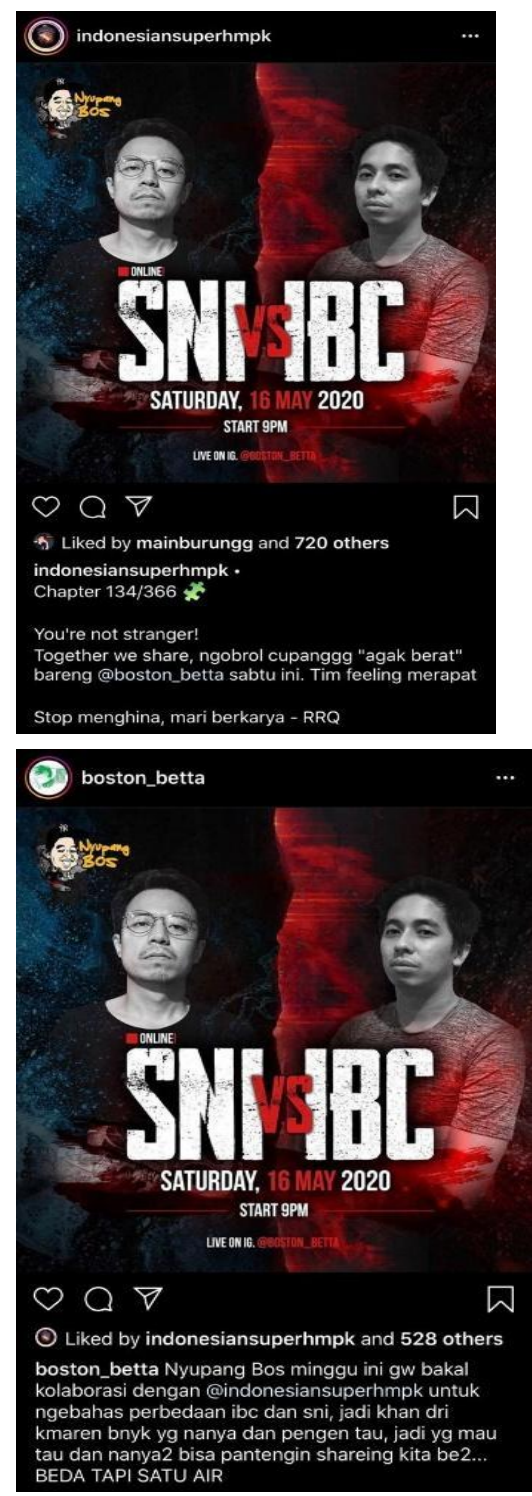

Gambar 10. Dukungan kedua kelompok Indonesia Super Hmpk dan Boston Betta di Instagram
Setelah melihat pola jaringan komunikasi pada kelompok sociopreneur ikan cupang wilayah Tangerang, untuk selanjutkan dapat dilakukan analisis fungsi individu dalam jaringan komunikasi komunikasi disebut (1) Star, yaitu seorang individu di dalam jaringan komunikasi yang paling dikenal, banyak memberikan masukan-masukan yang menjadi permasalahan yang ada, dan paling banyak dipilih oleh individu-individu lainnya di dalam sebuah kelompok. Selain itu juga dilihat dari banyaknya pilihan yang ditujukan kepada seseorang individu dari individu-individu lain dalam suatu jaringan komunikasi. Sebagai (2) Opinion Leader dimana ia menjadi pemuka pendapat dalam suatu kelompok jaringan 
komunikasi yang ditunjukkan dengan adanya individu yang memiliki jumlah hubungan komunikasi lebih banyak daripada rata-rata jumlah hubungan komunikasi antar individu-individu lain di dalam jaringan komuikasi. Ia sebagai sumber informasi bagi individu lainnya di dalam jaringan kelompok sociopreneur ikan cupang di wilayah Tangerang. Sebagai seorang opinion leader tentunya memiliki pengaruh informal terhadap individu-individu lainnya, dengan tujuan membuka pemikiran, merubah pemikiran, mengubah sikap dan perilaku terhadap inovasi-inovasi yang saat ini dihadapi. Di dalam grup Whats $A p p$ pun mereka menjalin komunikasi yang dilakukan opinion leader. Dalyano Kayambo atau Adon biasa menjawab pertanyaan-pertanyaan yang datang dari anggota kelompok lainnya dengan memberikan arahan sampai anggota kelompok mengerti dan paham. Disetiap jawaban Adon selalu memberikan pesan dan untuk kelompoknya, seperti memberikan motivasi hal-hal kecil, mengingatkan rasa syukur, dan ucapan semangat kepada anggota kelompoknya.

Penjelaskan diatas adalah mencerminkan implementasi teori yang digunakan dalam penelitian ini yaitu Interaksi Konvergensi Simbolik. Dimana teori ini menjelaskan bahwa komunikasi dalam kelompok harus dibangun untuk mencapai kesamaan pemikiran. Yang dimaksud kesamaan pemikiran adalah pemahaman yang sama antara opinion leader dengan anggota kelompok lainnya seperti cara ikan cupang untuk dapat mengikuti konten, cara menjual ikan cupang dengan kualitas yang baik, kualitas pakan ikan, cara ternak ikan cupang dengan menggunakan media sosial Instagram yang sudah dimiliki masing-masing anggota kelompok. Berdagang dengan inovasi-inovasi baru perlu dipelajari bersama dan dapat terus dikembangkan. Sehingga jika setiap individu dalam kelompok dapat saling pengertian, maka akan tercipta sebuah kesadaran bersama dalam pemikiran, perasaan dan semua hal-hal yang didiskusikan bersama. (3) Produktivitas adalah jumlah rasio dari sesuatu yang dihasilkan dari jumlah keseleruhan peralatan produksi yang digunakan. Sebuah produktifitas adalah bentuk interaksi yang terpadu secara bersamaan dari tiga faktor yang esensial, yaitu manajemen waktu, penggunaan pengetahuan dan teknologi, melakukan riset. Sehingga untuk lebih lanjut perlu juga dilakukan penelitian melalui hubungan komunikasi kelompok antar anggota dapat menjadikan dindividu termotivasi untuk dapat meningkatkan produktivitasnya.

\section{KESIMPULAN}

Setiap individu didalam kelompok mengetahui bahwa Dalyano Kayambo merupakan orang yang tepat untuk mereka tanya berbagai macam tentang cupang dan lainnya, strategi penjualan, bukan hanya kegiatan saja namun juga mampu bercerita berbagi pengalamannya selama tujuh tahun menggeluti bidang percupangan di Indonesia, selain itu mau memberikan ilmu-ilmu penting dan juga kegiatan sosial. Dengan demikian maka dapat terjalin kedekatan yang dapat menciptakan sebuah motivasi untuk dapat terus meningktakan produktifitas dan bisnis mereka secara online, hal ini juga dapat menjadikan acuan untuk dapat hidup lebih baik, sejahtera dan makmur secara lahir dan batin di dalam kelompok percupangan.

\section{SARAN}

Jaringan Komunikasi Indonesian Super Hmpk dan Boston Betta wilayah Tangerang ada juga beberapa anggota yang hanya ikut namun tidak tahu harus bagaimana, atau hanya sekedar ikut-ikutan supaya dapat status pengakuan dari individu di kelompok lain, dan ada juga yang pasif. Ini dapat 
dilihat bahwa komunikasi terjadi satu arah saja. Sehingga opinion leader mampu membaca kondisi yang ada sehingga ia berusaha untuk lebih aktif dalam melibatkan individu lain untuk bertanya, menyampaikan pendapatnya atau bahkan memberikan masukan, baik dilakukan secara tatap muka atau secara virtual. Dengan cara demikian diharapkan bagi individu-individu yang ada di dalam kelompok tersebut yang tadinya tidak tahu, masa bodoh atau pasif dapat lebih merasa dihargai atau diakui keber-adaannya sehingga mampu meningkatkan semangatnya yang memutuskan untuk berkecimpung di dunia percupangan Indonesia.

\section{DAFTAR PUSTAKA}

Azlina, A. (2015) Pengaruh Aktifitas Pada Instagram Terbadap Sikap Mahasiswi Pengguna Instagram Di Bandung (Studi Pada Instagram Fashion Blogger Sonia Eryka).

E-Proceeding of Management, Agustus, 2-2

Badan Pusat Statistik (2020) Ekonomi Indonesia Triwulan 12020 Tumbuh 2,97

Persen. https://www.bps.go.id/ pressrelease /2020/05/05/1736/ekonomi-indonesi a-triwulan-i-2020-tumbuh-2-97-persen. html. Diakses 14 Mei, 2020

Creswell, John. (2008) Research Design: Pendekatan, Kualitatif, Kuantitatif, dan Mixed. Bandung: Pustaka Pelajar.

Diah Ajeng P, Partini, Sri Peni. (2018) Tantangan Sociopreneurs Yogyakarta di Era Comm 3.0 Submitted: Maret 2018, Accepted: Mei 2018 Profetik Jurnal Komunikasi, hlm. 12-25

Eriyanto. (2014) Analisis Jaringan Komunikasi. Jakarta: Prenada Kencana

Infante, Dominic, et al. (1993) Building Communication Theory: Second Edition. USA: Waveland Press, Inc.

Irma Paramita Sofia. (2015) Kontruksi Model Kewirausahaan Sosial Sebagai Gagasan
Inovasi Sosial Bagi Pembangunan

Perekonomian. Jurnal Universitas

Pembangunan Jaya \#2 Volume 2 Maret 2015.

Kadushin, C. (2012) Understanding Social Networks: Theories, Concept, and Finding. New York: Oxford University Press.

Lilis Ramadanti, Yugih Setyanto. (2018) Pemanfaatan Instagram Dalam Sosialilasi Gerakan Selamatkan Pejalan Kaki (Studi pada Komunitas Koalisi Pejalan Kaki). Prologia, Vol. 2, No.2, Desember 2018, hlm 400-407. EISSN 2598-0777

Moleong, J Lexy. (2009) Metode Penelitian Kualitatif. Bandung: Remaja Rosdakarya,

Nasrullah, Rulli. (2015) Media Sosial Perspektif Komunikasi, Budaya, Dan Sosioteknologi). Jakarta: Simbiosa.

Neng Dewi, K., Riche Cinthya, J., Gema R. (2018) Hubungan Pemanfaatan Media Sosial Instagram Dengan Kemampuan Literasi Media Di UPT Perpustakaan Itenas2. E-journal.upi.edu. Tahun 8, Volume 8 No. 1 Mei 2018, hlm 1-17.

Pertiwi, Wahyunanda Kusuma. Sebanyak Inikah Jumlah Pengguna Instagram di Indonesia.https://tekno.kompas.com/r ead/2019/12/23/14020057/sebanyak-i nikah-jumlah-pengguna-instagram-di-in donesi. Diakses: 15 mei 2020.

Sinungan, Muchdarsyah. Produk-tivitas: Apa dan Bagaimana. Jakarta: Bumi Aksara.

Suryadi, Israwati. (2010) Teori Konvergensi Simbolik. Jurnal Academica FISIP Universitas Tadulako, Vol. 2, No. 2. Edisi Oktober 2010. ISSN 1411-3341

Tamburaka, Apriadi. (2013) Literasi Media: Cerdas Bermedia Khalayak Media Massa. Jakarta: PT. Rajagrafindo Persada.

Wibowo, Hery, S. A. N. (2015) Kewirausahaan Sosial Merevolusi Pola Pikir Menginisiasi Mitra Pembangunan. Unpad Press.

Yusuf, A. Muri. (2014) Metode Penelitian: Kuantitatif, Kualitatif, dan Penelitian Gabungan. Jakarta: Prenadamedia Group. 